\title{
Optimasi Potensi Bakteri Bacillus subtilis Sebagai Sumber Enzim Protease
}

\author{
Optimization of Bacterial Potential Bacillus subtilis as Source Enzyme Protease
}

\author{
Yempita Efendi, Yusra dan Vivi Oktavianis Efendi \\ Program Studi Pemanfaatan Sumberdaya Perikanan \\ Fakultas Perikanan dan Ilmu Kelautan Universitas Bung Hatta \\ Alamat: Kampus 1 Universitas Bung Hatta Jln. Sumatera Ulak Karang Padang \\ Fax: 07517055475, HP: 08126609378 Email : yempita@bunghatta.ac.id
}

\begin{abstract}
Abstrak
Penelitian ini bertujuan untuk menentukan keberadaan proteolitik, waktu optimum produksi dan aktivitas protease dari bakteri Bacillus subtilis. Metode yang digunakan adalah metode eksperimental, data dianalisa secara deskriptif kuantitatif. Bahan yang digunakan adalah bakteri Bacillus subtilis terseleksi yang berasal dari saluran pencernaan ikan Nila (Oreochromis niloticus). Hasil penelitian menunjukkan bahwa bakteri Bacillus subtilis mempunyai aktivitas proteolitik. Diameter zone hambat yang terbentuk menunjukkan secara kualitatif tingginya kemampuan proteolitik enzim protease yang dihasilkan atau juga tingginya jumlah enzim yang diproduksi dan dilepas keluar. Keberadaan enzim protease ekstraseluler ini sangat penting bagi kehidupan bakteri karena menyediakan kebutuhan senyawa bernitrogen yang dapat diangkut ke dalam sel. Jenis-jenis bakteri yang mempunyai kemampuan mensekresikan enzim protease ini memiliki potensi yang besar untuk digunakan sebagai agensia pembersih bahan pencemar yang bersifat protein. Jenis medium sangat berpengaruh terhadap produksi enzim protease bakteri Bacillus subtilis. Pola waktu optimum produksinya sejalan dengan pola kurva pertumbuhan bakteri secara umum. Hasil penelitian menunjukkan bahwa pada jam ke-46, bakteri menghasilkan aktivitas protease yang paling tinggi, yaitu sebesar 2,163 U/mL
\end{abstract}

Kata Kunci : Enzim Protease, Proteolitik, Bacillus substilis

\begin{abstract}
This research aim to determine the proteolytic, the optimum production time, and activity of protease from Bacillus subtilis bacteria.The method used the experimental design and data were analyzed by descriptive quantitative. The materials used Bacillus subtilis bacteria selected from the digestive tract Tilapia (Oreochromis niloticus). These results indicate that the bacterium Bacillus subtilis has proteolytic activity. The diameter of the inhibitory zone that was formed can qualitatively show the high ability of proteolytic protease enzyme which was produced or also the high amount of enzyme which was produced and released out. The existence of this extracellular protease enzyme is essential for life of bacteria as it provides needs nitrogenous compounds that can be transported into the cell. The types of bacteria that have the ability to secrete the protease enzyme has great potential to be used as a cleaning agent of protein contaminants. The type of medium significantly affects the production of Bacillus subtilis of bacterial Protease Enzyme and its optimum production time was in line with the pattern of the growth curve of bacteria in general. The results showed that at the 46th hour, the bacteria produced the highest protease activity, in the amount of $2.163 \mathrm{U} / \mathrm{mL}$
\end{abstract}

Keywords : protease enzymes, proteolytic, Bacillus substilis 


\section{Pendahuluan}

Protease merupakan enzim proteolitik yang mengkatalisis pemutusan ikatan peptida pada protein. Protease dibutuhkan secara fisiologi untuk kehidupan organisme pada tumbuhan, hewan maupun mikroorganisme. Protease tidak hanya berperan dalam proses metabolisme seluler, namun juga dapat diaplikasikan dalam bidang industri. Enzim ini merupakan salah satu enzim skala industri dengan tingkat penjualan hingga $60 \%$ dari total penjualan enzim di dunia. Aplikasi enzim protease misalnya pada industri pembuatan detergen, industri penyamakan kulit, bahan aditif pada industri pangan, dan zat terapeutik pada bidang farmasi (Gupta et al., 2002).

Protease dapat dihasilkan oleh tumbuhan, hewan, dan mikroorganisme. Penggunaan tumbuhan sebagai sumber protease terbatas oleh tersedianya lahan tanam dan kondisi pertumbuhan yang sesuai, serta memerlukan waktu produksi enzim yang lama. Produksi protease dari hewan juga dibatasi oleh ketersediaan ternak penghasil enzim. Mikroorganisme merupakan sumber enzim yang paling potensial dibandingkan tanaman dan hewan. Penggunanan mikroorganisme lebih menguntungkan karena pertumbuhannya cepat, dapat tumbuh pada substrat yang murah, lebih mudah ditingkatkan hasilnya melalui pengaturan kondisi pertumbuhan dan rekayasa genetik. Beberapa genus bakteri yang diketahui mampu menghasilkan protease adalah Bacillus, Lactococcus, Streptomyces, dan Pseudomonas (Said dan Likadja, 2012).

Spesies Bacillus sp. merupakan salah satu mikroba penghasil enzim protease yang potensial. Beberapa enzim protease komersial berhasil dimurnikan, misalnya Alcalase dari Bacillus licheniformis, Esperase dari Bacillus lentus, Biofeed pro dari Bacillus licheniformis dan Subtilisin dari Bacillus alcalophilus (Gupta et al., 2002). Tari et al,. (2005) melaporkan bahwa Bacillus sp. L21 dapat menghasilkan enzim protease yang bersifat tahan basa. Sementara itu, Suganthi et al., (2013) melaporkan bahwa Bacillus licheniformis dapat menghasilkan enzim protease yang bersifat halotoleran. Berdasarkan latar belakang di atas penelitian ini bertujuan untuk melakukan produksi dan optimasi enzim ptotease dari bakteri Bacillus subtilis yang diisolasi dari saluran pencernaan ikan Nila (Oreochromis niloticus) yang dibudidayakan di
Karamba Jaring Apung (KJA) Danau Maninjau yang diharapkan dapat dijadikan sebagai kandidat probiotik.

\section{Bahan dan Metode}

Penelitian dilakukan mulai bulan Maret 2016 sampai dengan bulan Oktober 2016. Analisa dilakukan di Laboratorium Mikrobiologi dan Laboratorium Terpadu Fakultas Perikanan dan Ilmu Kelautan Universitas Bung Hatta dan Laboratorium Kimia Fakultas Matematika dan Ilmu Pengetahuan Alam Universitas Andalas Padang dan Laboratorium Kopertis Wilayah X Padang.

Bahan yang digunakan dalam penelitian ini adalah isolat bakteri terpilih Bacillus subtilis yang diisolasi dari saluran pencernaan ikan Nila (Oreochromis niloticus) yang dibudidayakan di karamba jaring apung Danau Maninjau. Bahan-bahan kimia yang digunakan adalah: medium TSB, amoniumsulfat, bufer pospat, buffer asetat, bufer borat, pakan komersil, Trichloro Acetic Acid (TCA), aquades, aquabidest, tirosin, kasein, reagen Bradford, pereaksi folin fenol ciocalteau's, bovin serum albumin (BSA).

Peralatan yang digunakan dalam penelitian ini adalah cawan petri, tabung reaksi, erlenmeyer, gelas piala, jarum ose, pipet tetes, spatula, bunsen, pengaduk magnetik, pipet mikro, spektrofotometer UV-VIS (Thermo Spectronic Genesys 20), sentrifuse dingin (Hettich Zentrifugen Universal 320R), neraca analitik (KERN ABJ), inkubator (Gallenkamp), autoklaf (Certo Clav) dan akuarium

\section{Uji Proteolitik Bakteri Bacillus subtilis}

Uji proteolitik dilakukan dengan media skim milk agar (SMA) yaitu media LBA yang ditambah dengan susu skim 2\%. Isolat dimasukkan dalam media SMA, lalu diinkubasi selama 24 jam pada suhu $37^{\circ} \mathrm{C}$. Aktivitas proteolitik dari bakteri Bacillus subtilis yang ditumbuhkan pada media SMA ditujukan dengan terlihatnya arel bening disekitar koloni yang terbentuk. Indeks proteolitik dihitung dengan cara mengukur diameter areal bening dan diameter koloni bakteri. Perhitungan indeks proteolitik adalah perbandingan diameter areal bening dengan diameter koloni bakteri. 
Penentuan Waktu Optimum Produksi Protease dari bakteri Bacillus subtilis

Bakteri diinokulasi sebanyak 1 sampai 2 ose pada media Luria Britani Broth (LB) dengan komposisi medium tripton $1 \%, \mathrm{NaCl} 1 \%$ dan yeast ekstrak $0,5 \%$. Proses diawali dengan penentuan umur prekultur produksi protease (dalam medium LB). Produksi protease dilakukan pada suhu $37^{\circ} \mathrm{C}$. Pengamatan dilakukan dengan mengukur optical density (OD) sampai nilai $\mathrm{OD}=0,8$ pada $\lambda=620 \mathrm{~nm}$. Media LB yang sudah mempunyai OD $=0,8$ diambil $10 \%$ dari jumlah media, kemudian ditambahkan pada media LB yang baru sebagai media untuk produksi protease. Pengambilan sampel dilakukan setiap 8 jam selama 64 jam dan diukur nilai OD, aktivitas protease dan kadar protein. Ekstraksi enzim protease dilakukan dengan cara sentrifugasi media pertumbuhan bakteri dengan kecepatan 3.000 rpm selama 15 menit pada suhu $4^{\circ} \mathrm{C}$. Dengan teknik ini, sel akan mengendap oleh adanya gaya gravitasi sedangkan enzim tetap terdapat pada supernatan. Supernatan sebagai sampel diuji aktivitas protease dan kadar proteinnya.

\section{Penentuan Aktivitas Protease dari Bakteri Bacillus subtilis}

Aktivitas protease diukur dengan metode Bergmeyer et al., (1983) dengan menggunakan substrat kasein Hammerstein 2\% (b/v). Prosedur pengujian aktivitas protease adalah mereaksikan $0,2 \mathrm{ml}$ enzim yang berasal dari bakteri Bacillus subtilis dengan $1 \mathrm{ml}$ substrat kasein Hammerstein dan $1 \mathrm{ml}$ bufer. Campuran reaksi diinkubasi pada suhu $37^{\circ} \mathrm{C}$ selama 10 menit, kemudian ditambahkan 0,2 M TCA. Selanjutnya larutan diinkubasi kembali pada suhu $37^{\circ} \mathrm{C}$ selama 10 menit, dilanjutkan dengan sentrifugasi pada kecepatan $5.000 \mathrm{rpm}$ 10 menit. Dari campuran hasil sentrifugasi diambil supernatan dan ditambahkan kedalam tabung reaksi yang berisi $\mathrm{Na}_{2} \mathrm{CO}_{3} \quad 0,4 \mathrm{M}$ kemudian ditambahkan pereaksi folin ciocalteau (1 : 2) dan diinkubasi pada suhu $37^{\circ} \mathrm{C}$ selama 20 menit. Hasil inkubasi diukur dengan spektrofotometer pada $\lambda=578 \mathrm{~nm}$. Satu unit aktivitas protease didefinisikan sebagai jumlah enzim yang dapat menghasilkan satu $\mu$ mol produk tirosin per menit pada kondisi optimum pengukuran.

\section{Pengukuran Kadar Protein dari Enzim Protease}

Kadar protein ditemtukan dengan metode Bradford (2976) menggunakan Bovine Serum Albumin (BSA) Fraction V sebagai standar protein. Sebanyak $100 \mathrm{mg}$ BSA ditimbang dan ditambahkan $25 \mathrm{ml}$ aquades. Larutan kemudian dikocok pelan-pelan, setelah larut diencerkan sampai $50 \mathrm{ml}$. Konsentrasi akhir larutan stok untuk standar ini adalah $2 \mathrm{mg} / \mathrm{ml}$. Kemudian sederetan larutan standar dibuat dengan menggunakan larutan stok di atas. Langkah selanjutnya adalah memipet masing-masing larutan sampel dalam tiap tabung sebanyak 0,1 $\mathrm{ml}$ sebanyak $5 \mathrm{ml}$ pereaksi Bradford ditambahkan kedalam masing-masing tabung reaksi. Blanko dibuat dengan cara mencampurkan $0,1 \mathrm{ml}$ dan direaksikan dengan $5 \mathrm{ml}$ pereaksi Bradford. Setelah sekitar 5 menit, masing-masing campuran reaksi diukur absorbansinya pada $\lambda=595 \mathrm{~nm}$

\section{Analisis data}

Data yang diperoleh ditabulasi kemudian dianalisis secara diskriptif kuantitatif.

\section{Hasil dan Pembahasan}

\section{Uji Proteolitik Bakteri Bacillus subtilis}

Hasil penelitian ini menunjukkan bahwa bakteri Bacillus subtilis mempunyai aktivitas proteolitik. Pada penelitian ini difokuskan salah satunya pada jenis enzim proteolitik karena komponen utama pakan ikan adalah protein. Hasil pengujian secara kualitatif ditunjukkan dengan adanya zona bening di sekitar koloni mikroba. Hasil pengujian secara kualitatif adalah dengan adanya lingkaran bening di sekitar koloni dan pengujian secara semikualitatif adalah hasil bagi diameter lingkaran jernih dengan diameter koloni dan dinyatakan sebagai aktivitas protease secara relatif

Berdasarkan hasil penelitian diperoleh bakteri Bacillus subtilis mempunyai kemampuan menghasilkan enzim proteolitik ekstraseluler. Diameter zone hambat yang terbentuk dapat menunjukkan secara kualitatif tigginya kemampuan proteolitik enzim protease yang dihasilkan atau juga tingginya jumlah enzim yang diproduksi dan dilepas keluar. Adapun nilai indeks proteolitik dari isolat bakteri Bacillus subtilis 
Yempita Efendi : Optimasi Potensi Bakteri Bacillus subtilis Sebagai Sumber Enzim Protease

terpilih dapat dilihat pada Gambar 1.

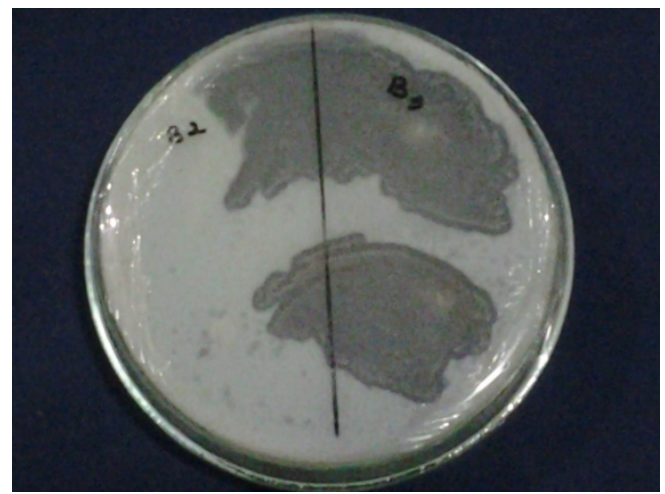

Gambar 1. Hasil Uji Aktivitas Proteolitik Isolat Bakteri Bacillus subtilis pada Medium Skim Milk Agar (SMA) .

Figure 1. Test Results of proteolytic activity Bacterial Isolates of Bacillus subtilis on Medium Skim Milk Agar (SMA).

Pengaruh Jenis Medium terhadap Akrivitas Enzim Protease dari bakteri Bacillus subtilis

Hasil pengujian pengaruh jenis medium produksi terhadap aktivitas spesifik enzim protease menunjukkan bahwa bakteri Bacillus subtilis setelah dilakukan inkubasi selama 48 jam pada suhu $37^{\circ} \mathrm{C}$ memiliki pengaruh yang berbeda- beda tergantung pada jenis atau komposisi medium seperti terlihat pada Tabel 1 dan Gambar 2 .

Tabel 1. Jenis Medium Produksi Enzim Protease Bakteri Bacillus subtilis

Table 1. Type Medium Bacterial Protease Enzyme Production of Bacillus subtilis

\begin{tabular}{lll}
\hline No & \multicolumn{1}{c}{ Jenis Medium } & \multicolumn{1}{c}{ Reaksi } \\
\hline $\mathbf{1}$ & A (GYS) & Keruh, banyak endapan \\
$\mathbf{2}$ & B (Horikoshi) & Bening, sedikit endapan \\
$\mathbf{3}$ & C (GP) & Bening, sedikit endapan \\
$\mathbf{4}$ & D (Son) & Agak keruh, sedikit endapan \\
\hline
\end{tabular}
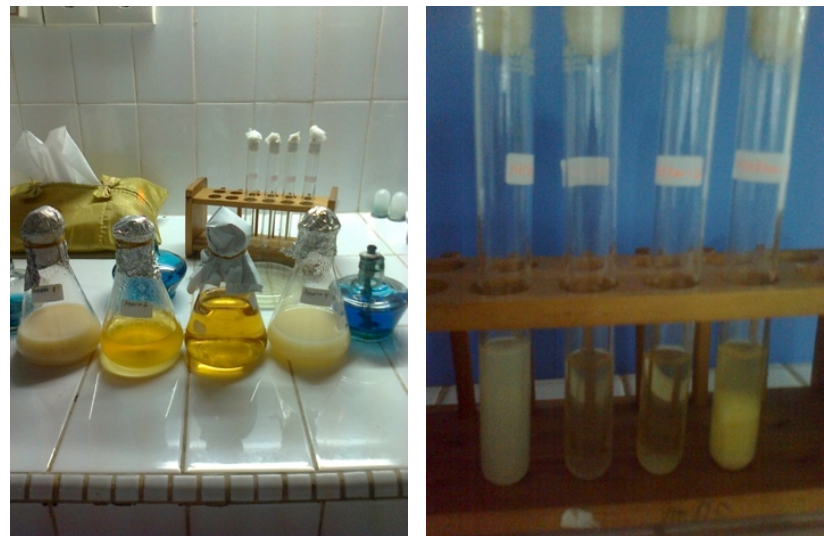

Gambar 2. Jenis Medium Produksi Enzim Protease Bakteri Bacillus subtilis dan Aktivitas setelah Inkubasi

Figure 2. The Type of Medium of Bacterial Protease Enzyme Production of Bacillus subtilis and Activities after Incubation

Medium GYS secara kasat mata menghasilkan aktivitas tertinggi diantara medium lainnya. Berdasarkan Gambar 2 terlihat bahwa terdapat banyak endapan pada dasar tabung reaksi dibandingkan medium B, $\mathrm{C}$ dan D. Hal ini ditandai dengan kultur yang berwarna keruh pada pengamatan selama 48 jam. Kultur bakteri yang semula tidak 
memiliki endapan berubah warna menjadi keruh sebagai tanda terjadinya pertumbuhan bakteri setelah masa inkubasi yang disebabkan oleh proses metabolisme yang dilakukan oleh bakteri tersebut. Di dalam medium cair bakteri akan tumbuh dalam waktu 24 - 48 jam. Pertumbuhan bakteri dalam suatu media cair dapat terlihat dalam berbagai bentuk, yaitu: 1). Kekeruhan yang biasanya terlihat pada seluruh bagian medium, 2). Pertumbuhan pada permukaan yang dapat berbentuk pelikel (pertumbuhan di atas bagian media cair), cincin (pertumbuhan berbentuk cincin pada permukaan media cair), flokulen atau membran. 3). Sedimen atau endapan, yaitu kumpulan sel-sel yang mengumpul pada dasar tabung dan akan menyebar lagi jika tabung digerakkan atau dikocok. Medium pada bagian atas tabung mungkin akan tetap bening jika inkubasi dilakukan lebih lama. Untukmengetahui aktivitas spesifik enzim dari masing-masing medium dilakukan dengan optimasibakteri Bacillus subtilis pada medium yang cocok dengan interval waktu inkubasi 0 , $6,12,18$ dan 24 jam di atas shaker pada kecepatan $120 \mathrm{rpm}$ dan suhu $37^{\circ} \mathrm{C}$. Aktivitas spesifik enzim protease diukur menggunakan spektrofotometer pada panjang gelombang $620 \mathrm{~nm}$ dapat dilihat pada Tabel 2.

Tabel 2. Pengaruh Jenis Medium terhadap Aktivitas Enzim Protease

Table 2. Effect of the Medium Type Protease Enzyme Activity

\begin{tabular}{lcc}
\hline No & Medium Produksi & Aktivitas Spesifik Enzim (U/mg) \\
\hline 1 & A (GYS) & 2,090 \\
2 & B (Son) & 1,936 \\
3 & C (LB) & 2,163 \\
\hline
\end{tabular}

Penentuan Waktu Optimum Produksi Protease dari bakteri Bacillus subtilis

Bakteri pada media produksi tersebut diinkubasi pada suhu $37^{\circ} \mathrm{C}, 120 \mathrm{rpm}$ selama \pm 3 hari. Setiap 6 jam dilakukan sampling untuk pengukuran pertumbuhan mikroba (Pengukuran OD), uji aktivitas serta analisis kadar proteinnya. Hasil pengujian optical density (OD) dan uji aktivitas enzim berdasarkan waktu fermentasi terlihat pada Tabel 3.

Secara teoritis kultur Bacillus subtilis menghasilkan asam laktat dalam jumlah yang relatif tinggi karena ditumbuhkan dalam medium MRSB yang mengandung sumber karbon yang cukup untuk dimanfaatkan secara optimal dalam aktivitas metabolismenya. Pada saat populasi mikroba mulai stasioner maka produksi asam laktat juga stasioner atau bertambah dengan peningkatan yang relatif sedikit. Hal ini kemungkinan disebabkan karena jumlah zat gizi dalam media pada fase ini sudah mengalami penurunan. Penggunaan substrat oleh mikroba tidak lagi untuk pertumbuhan dan produksi asam laktat, tetapi lebih banyak untuk metabolisme sekunde.

Tabel 3. Data hasil penentuan waktu produksi optimum protease dari bakteri dan optical density

(OD) menggunakan medium MRSB

Table 3. Data from the timing of the optimum production of bacterial protease and optical density (OD) using a medium MRSB

\begin{tabular}{lcc}
\hline No & Waktu Fermentasi (Jam) & Optical Density (OD) \\
\hline 1 & 0 & 0,028 \\
2 & 6 & 0,057 \\
3 & 12 & 0,071 \\
4 & 18 & 0,129 \\
5 & 24 & 0,132 \\
\hline
\end{tabular}




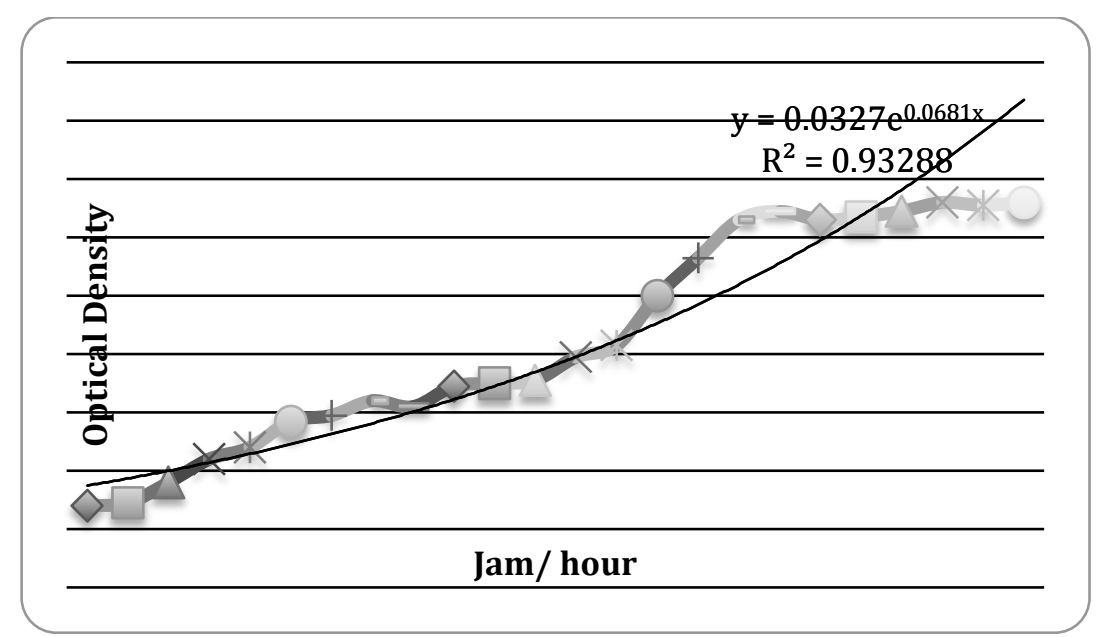

Gambar 3. Waktu Produksi Optimum Enzim Protease dari Bakteri Bacillus subtilis dan Optical Density (OD)

Figure 3. The Optimum Production Time of Protease Enzyme of Bacillus subtilis bacteria and Optical Density (OD)

Pengamatan fase pertumbuhan bakteri dilakukan dengan mengamati perubahan populasi dan nilai kerapatan optik (optical density = OD). Hal ini berhubungan dengan waktu panen sel bakteri dalam memproduksi suatu produk atau senyawa metabolit, diantaranya adalah enzim, antibakterial, vitamin dan asam organik.

Gambar 3 menggambarkan bahwa fase pertumbuhan isolat bakteri Bacillus subtilis terdiri dari empat fase yakni fase lag, fase eksponensial, fase stasioner dan fase kematian. Pada fase lag biasanya bakteri melakukan proses aklimatisasi terhadap kondisi lingkungan seperti $\mathrm{pH}$, suhu, nutrisi dan lain sebagainya. Pertumbuhan jumlah bakteri pada fase lag berlangsung lambat. Fase lag untuk isolat bakteri Bacillus subtilis VITNJ1 berlangsung selama jam ke-1 sampai jam ke - 2. Fase kedua adalah fase eksponensial yang merupakan fase dimana pertumbuhan bakteri berlangsung sangat cepat. Fase eksponensial isolat bakteri Bacillus subtilis VITNJ1 terjadi pada jam ke - 3 sampai jam ke - 18.

Fase berikutnya adalah fase stasioner yakni terjadi pada jam ke-19 sampai jam ke-24, dimana pada fase ini tidak terjadi penambahan jumlah sel bakteri karena jumlah sel yang tumbuh sama dengan jumlah sel yang mati. Fase terakhir adalah fase kematian yang pada isolat bakteri Bacillus subtilis mulai terjadi setelah jam ke-24, dimana pada fase ini jumlah sel bakteri mulai menurun karena nutrien dalam media dan cadangan energi dalam sel mulai menipis.

Berdasarkan Gambar 3 pada fase logaritmik (sebelum memasuki fase eksponensial) terjadi pada jam ke-2. Secara teoritis kultur Bacillus subtilis menghasilkan asam laktat dalam jumlah yang relatif tinggi karena ditumbuhkan dalam medium MRS broth yang mengandung sumber karbon yang cukup untuk dimanfaatkan secara optimal dalam aktivitas metabolismenya. Pada saat populasi mikroba mulai stasioner maka produksi asam laktat juga stasioner atau bertambah dengan peningkatan yang relatif sedikit. Hal ini kemungkinan disebabkan karena jumlah nutrisi dalam media pada fase ini sudah mengalami penurunan. Penggunaan substrat oleh mikroba tidak lagi untuk pertumbuhan dan produksi asam laktat, tetapi lebih banyak untuk metabolisme sekunder yaitu menghasilkan metabolit yang lain diantaranya adalah bakteriosin.

Untuk hasil pengujian optical density (OD) dan uji aktivitas enzim berdasarkan waktu fermentasi menggunakan medium Luria Bertani (LB) terlihat pada Tabel 4. Hasil pengamatan menunjukkan bahwa pertumbuhan bakteri mengalami fase adaptasi pada jam ke-8 hingga jam ke24. Selama waktu tersebut bakteri mulai menyesuaikan diri dengan lingkungan yang baru, sehingga sel belum membelah. Fase eksponensial terjadi pada jam ke-24 hingga jam ke-36. Pada fase eksponensial sel-sel bakteri sangat aktif membelah dan 
metabolisme sel berlangsung cepat. Pertumbuhan bakteri mulai melambat ketika memasuki fase stasioner, yaitu mulai pada jam ke-46, hal ini disebabkan nutrisi dan substrat di dalam media mulai berkurang, sehingga kematian sel meningkat. Jumlah sel yangmati semakin meningkat sampai terjadi suatu keadaan dimana jumlah sel yang hidup samadengan jumlah sel yang mati. Fase kematian terjadi pada jam ke-50, hal ini terjadi karena jumlah substrat dan nutrisi hampir habis, sehingga sel semakin lama sudah tidak dapat tumbuh lagi. Pada bakteri, pertumbuhan optimal sel berada pada fase eksponensial. Berdasarkan hasil penentuan kurva produksi protease , dapat disimpulkan bahwa aktivitas protease berkorelasi positif terhadap pertumbuhan bakteri. Semakin besar jumlah sel, maka semakin besar juga aktivitas protease yang dihasilkan. Hasil penelitian menunjukkan bahwa pada jam ke46, bakteri menghasilkan aktivitas protease yang paling tinggi, yaitu sebesar $2,163 \mathrm{U} / \mathrm{mL}$ yang digunakan sebagai waktu inkubasi optimum. Tahap akhir dari proses produksi enzim protease dari bakteri adalah isolasi dengan menggunakan sentrifus pada kecepatan $3500 \mathrm{rpm}$ selama 15 menit. Supernatan yang diperoleh merupakan ekstrak kasar protease.

Tabel 4. Data hasil penentuan waktu produksi optimum protease dari bakteri dan optical density (OD) menggunakan medium LB

Table 4. The result of the timing of the optimum production of bacterial protease and optical density (OD) using LB medium

\begin{tabular}{ccc}
\hline No & Waktu Fermentasi (Jam) & Optical Density (OD) \\
\hline $\mathbf{1}$ & 0 & 0,034 \\
$\mathbf{2}$ & 2 & 1,005 \\
$\mathbf{3}$ & 4 & 1,393 \\
$\mathbf{4}$ & 6 & 1,537 \\
$\mathbf{5}$ & 8 & 1,538 \\
$\mathbf{6}$ & 10 & 1,544 \\
$\mathbf{7}$ & 12 & 1,595 \\
$\mathbf{8}$ & 14 & 1,664 \\
$\mathbf{9}$ & 16 & 1,703 \\
$\mathbf{1 0}$ & 18 & 1,834 \\
$\mathbf{1 1}$ & 20 & 1,838 \\
$\mathbf{1 2}$ & 24 & 1,95 \\
$\mathbf{1 3}$ & 26 & 1,979 \\
$\mathbf{1 4}$ & 28 & 1,981 \\
$\mathbf{1 5}$ & 30 & 1,988 \\
$\mathbf{1 6}$ & 32 & 2,091 \\
$\mathbf{1 7}$ & 34 & 2,094 \\
$\mathbf{1 8}$ & 36 & 2,108 \\
$\mathbf{1 9}$ & 38 & 2,123 \\
$\mathbf{2 0}$ & 40 & 2,129 \\
$\mathbf{2 1}$ & 42 & 2,133 \\
$\mathbf{2 2}$ & 44 & 2,134 \\
$\mathbf{2 3}$ & 46 & 2,147 \\
$\mathbf{2 4}$ & 48 & 2,163 \\
$\mathbf{2 5}$ & 50 & 2,153 \\
\hline & & \\
\hline
\end{tabular}


Yempita Efendi : Optimasi Potensi Bakteri Bacillus subtilis Sebagai Sumber Enzim Protease

\section{Kesimpulan dan Saran}

\section{Kesimpulan}

Bakteri Bacillus subtilis memiliki kemampuan proteolitik. Dan dipengaruhi oleh jenis medium. Pola waktu produksi optimum protease Bacillus subtilis sejalan dengan pola kurva pertumbuhan bakteri secara umum dengan aktivitas protease tertinggi dicapai pada jam ke-46, yaitu sebesar 2,163 U/mL.

\section{Saran}

Disarankan untuk melakukan penelitian lanjutan tentang uji penentuan waktu optimum produksi protease dan aktivitas protease dari bakteri Bacillus subtilis serta pengukuran kadar protein dari enzim protease.

\section{Ucapan Terima Kasih}

Terima kasih penulis ucapkan kepada Direktorat Riset dan Pengabdian Kepada Masyarakat, Dirjen Penguatan Riset dan Pengembangan Kementrian Riset dan Pendidikan Tinggi yang telah membiayai penelitian ini

\section{Daftar Pustaka}

Gupta, R., Q. K. Beg and P. Lorenz. 2002. Bacterial alkaline proteases : molekular approaches and industrial applications. Applied Microbial Biotechnology, 59: 15-32.

Said, M. I dan J. C. Likadja. 2012. Isolasi dan identifikasi bakteri yang berpotensi sebagai penghasil enzim protease pada industri penyamakan kulit PT. Adhi Satria Abadi (ASA), Yogyakarta. JITP, 2 (2): 121-128.

Suganthi, C. A. Mageswari., S. Karthikeyan., M. Anbalagam., A. Sivakumar and K. M. Gothandam. 2013. Screening and optimization of protease production of a halotolerant Bacillus licheniformis isolated from saltern sediments. Journal of Genetic Engineering and Biotechnology. 11(1): 47-52.

Tari, C., H. Genckal dan F. Tokatl. 2005. Optimization of a growth medium using a statistical approach for the production of an alkaline protease from a newly isolated Bacillus $s p$. L21. Process Biochemistry. 41:659-665. 